\title{
SOME TACTICAL ELEMENTS FOR ARCHERS IN THE ROMAN ARMY
}

\begin{abstract}
This paper follows issues of tactical fight for a special category of troops of the Roman army, namely the archers. Archers troops usually have in its name the indicative sagittarii, sagittaria, sagittariorum. These troops are of two types: pedestrian and mounted.
\end{abstract}

Keywords: archers, bow, arrow, beaten zone, mounted archers

$\mathbf{T}$ he Roman Empire's military vision has in its centre the troops of legionary heavy infantry. In time, due to the challenges arising from the extent of the territory and therefore confronting new enemies who have various combat tactics, the Roman generals felt the need to adapt. Therefore they introduced specialized auxiliary troops. This paper follows issues of tactical fight for a special category of troops, namely the archers. Archers troops usually have in its name the indicative sagittarii, sagittaria, sagittariorum ${ }^{1}$. These troops are of two types: pedestrian and mounted.

The archers were first mentioned in connection with Scipio's army from Hispania, and these were organized in small groups corresponding to the legionary centuriae ${ }^{2}$. Incorporating them into the Roman army as regular units would be still a long process. The archers will not be used from the end of the Punic wars until Caesar's campaigns in Gallia. Caesar uses in these campaigns Cretan and Numidian archers ${ }^{3}$, and it mentions the presence of some solid units of Gauls archers in Vercingetorix's army ${ }^{4}$.

All the archers in the Roman army, be they on foot or mounted, used the "Mediterranean" shooting technique ${ }^{5}$, the oldest known technique ${ }^{6}$. The mechanics of launching an arrow is based on three actions: stretching the cord, keeping the cord stretched, taking aim and releasing the cord and the arrow $^{7}$. The archer fixes the arrow in the cord, turns towards the target and raises the bow with the left hand stretched in front, holding it vertically, at the same time pulls the cord with the right hand until it reaches the chin, the right shoulder or the right ear ${ }^{8}$, he takes aim looking over or under the arrow, depending on the distance to the target. While stretched, the cord is held with a finger above the arrow and with another one or two under it ${ }^{9}$ (Fig1,

\footnotetext{
1 ŢENTEA 2007, 153; T,ENTEA 2012, 102.

2 FEUGËRE 1993, 211.

3 CAESAR, BG 2.7; DAVIES 1977, 261; GILLIVER 2005, 16.

4 CAESAR, $B G$ 7.31; 7.36; 7.80.

5 STEPHENSON 1999, 85.

6 MORSE 1885, 4.

7 MCALLISTER 1993, 13.

8 PROCOPIUS 1.1.15.

9 GOLDSWORTHY 1996, 185; COULSTON 1985, 278.
}

\section{Petru Ureche}


2,b). It is preferred that the archer not to stand to much with the bow stretched in order to reduce the fatigue and the shaking ${ }^{10}$. In the case of the Mediterranean technique, the arrow is held on the left side of the bow ${ }^{11}$.

Another well known shooting technique is the "Mongolian" one, which states the support of the arrow between the thumb and the pointer finger ${ }^{12}$. This technique utilizes a ring, usually made of bone, to protect the thumb from cord friction (Fig2, b). These type of rings have not been discovered before the Byzantine period, that is why it is supposed that this technique was not employed by the Roman $a^{2} y^{13}$. In this technique the arrow is held on the right side of the bow ${ }^{14}$. The Sasanian archers have never adopted the Mongolian shooting technique, which they considered to be barbarian. They stretched the cord with the middle and ring fingers, the pointer finger and possibly the thumb were used for supporting the arrow. The saracen archers used protection for the tip of their fingers in order to avoid cord wounds. The finger protections were fixed with the aid of small chains, that after were tied around the wrist they formed a cross on the back of the palm and the two ends were tied around the middle finger ${ }^{15}$.

\section{THE PEDESTRIAN ARCHERS}

The archers have an important role in the beginning of the battle trying to demoralize and disorganize the enemy by causing great loses from afar ${ }^{16}$. Their purpose in the beginning of the battle is to create gaps in the enemy's attack line and, if possible, to eliminate as many components of the adversary's commands. Thus, in case of an attack by heavy infantry or heavy cavalry ${ }^{17}$ the loses were minimized for their own side and the enemy would become more vulnerable ${ }^{18}$.

During the fight, the archers are intended to support other troops by standing behind them and shooting their arrows above them ${ }^{19}$, in between the heavy infantry's intervals, or on the flanks ${ }^{20}$. Thus, very often, the archers along with the slingers or the cavalry ${ }^{21}$ would offer support to the heavy infantry against the attacks of the enemy's cavalry $^{22}$. Titus ${ }^{23}$, and later on Valerianus, together with Anullius $^{24}$ (Septimius Severus' generals) have placed their archers and spearmen behind the legions in order for them to shoot the arrows and spears above their line. This is the solution Arrian propose to adopt against the Alans ${ }^{25}$. Although this type of positioning was criticized by some military art theorists, because the archer had to shoot above the infantry's front rows, thus decreasing quite a lot the

\footnotetext{
MCALLISTER 1993, 15.

MORSE 1885, 4.

MCALLISTER 1993, 14.

COULSTON 1985, 275-278.

MORSE 1885, 5.

FARROKH/MCBRIDE 2005, 14

GILLIVER 2008, 130.

BRADBURY 1985, 28

GOLDSWORTHY 1996, 234.

ARRIAN, Alani 18, 21, 26.

CASSIUS DIO 75.7.2; COWAN 2011b, 284

CAESAR, BC 3.88.6; 3.93.3.

GOLDSWORTHY 1996, 190.

FLAVIUS JOSEPHUS, BJ 5.130-5.135.

24 CASSIUS DIO 75.7.

25 ARRIAN, Alani 18, 25-26.
}

range of the arrow and the acuity of the strike ${ }^{26}$, it can not be negated the utility for their protection and for the fact that they could continue shooting even after the battle line was at close range. If the army was positioned on a slope the shooting range would increase ${ }^{27}$.

Another example for the archer's positioning often described during the battles is on the heavy infantry's flanks ${ }^{28}$, alongside to the slingers and other soldiers specialized in projectile launching. The modern authors have interpreted this positioning as being a tactic to protect in flanks ${ }^{29}$. Because it's well known even from Antiquity the archers' vulnerability ${ }^{30}$, this explanation is not plausible. This explanation is based on the "small firearms theory" 31 . This supports that no weapon can hit a target in the same place every time no matter its accuracy. This depends on various factors: variations of the projectiles' mass, variations of propulsion, disruptions in the air which increase or shorten the length of the soaring or the deviation. The projectiles shot by an army towards a target would describe a cone, that when it intersects with the ground creates the so called beaten zone (Fig3) with an elliptical form, with its long axis parallel on the line of the weapon to the target. The battle zone may vary according to the appearance of the terrain. In order for the projectile launching troops to have a greater efficiency they must be placed so the long axis of their battle zone to coincide with the target's long axis, this being possible by placing them on the flanks ${ }^{32}$.

An unusual example for utilizing the archers is when Titus used his archers during the siege of Jerusalem in street combats $^{33}$

\section{THE MOUNTED ARCHERS}

As it is the case with pedestrian archers, even though the Roman generals have experimented on themselves the utility of the mounted archers, there is no proof of using this type of troops in the Roman army until the Civil wars between Caesar and Pompei, when the latter receive from Antiochus of Commagene a contingent of archers on horse ${ }^{34}$. They are mentioned, along side the pedestrian ones in Germanicus's army during the campaign against the Chat $i i^{35}$, but the actual troops of mounted archers will be created only in the Flavian dynasty, when the Roman army's purpose was to remedy its inefficiency against the Sarmatians and the Dacians. Now, for the first time, we have regulated units of archers on horse recruited almost exclusively in the Eastern Empire ${ }^{36}$. These troops have been used in wars and as garrison troops on the limes in Pannonia, Dacia, Germania ${ }^{37}$, Britannia ${ }^{38}$, the north of Africa and in Levant ${ }^{39}$.

\footnotetext{
ONASANDER 17.

GILLIVER 2008

ARRIAN, Alani 12-14; CAESAR, BAfr. 60, 81.

COULSTON 1985, 292-294.

CAESAR, $B G$ 7.80.7, BC 3.93-3.94.

MCALLISTER 1993, 103.

MCALLISTER 1993, 102-106.

FLAVIUS JOSEPHUS, BJ 5.8.1.

CAESAR, BC 3.4.5.

TACITUS, Ann. 2.16.

EADIE 1967, 166; WHEELER 2007, 261.

Cohors I Flavia Damascenorum.

Cohors Hamiorum sagittariorum.

MCALLISTER 1993, ii, 2, 95-101.
} 
Flavius Josephus offers numerous details about the utilization of there archers, especially as protection for the army on the march ${ }^{40}$, and Tacitus about their actions of attack and pursuit ${ }^{41}$. A very important source regarding this type of troops is Arrian, whose army included mounted archers. Ammianus Marcellinus considers them formidable thanks to their armor, but unfortunately speaks little and extremely rare about these riders in order for the information to be used $^{42}$.

Sadly, Vegetius doesn't mention at all the archers on horse, but he does offer precious information regarding archers and the cavalry in general ${ }^{43}$. There is enough information about the archers on horse in the VI-VII A.D. centuries which can be useful even for the Principate period. Procopius, in Bellum Gothicum, frequently describes the Roman army battle line in the $6^{\text {th }}$ century A.D., which was mainly composed of mounted archers ${ }^{44}$, and the Emperor Mauricius' Strategikon contains references regarding the training and utilization of both the archers on horse and on foot $^{45}$.

The majority of the archers on horse were raised from the Eastern Empire population, that were famous for their ability in archery and in riding ${ }^{46}$, because utilizing with great precision a bow while on horse necessitated a skilled rider. The horses were trained in such a way that they didn't act negatively when the archer squeezed his knees in order to rise in the moment of launching the arrow ${ }^{47}$. Also, when additions to this troops were needed, the recruitment was not done locally, as was the case concerning other troops, but in the area of origin of the troop ${ }^{48}$.

During the march the mounted archers had a well established and important role in the avant-garde and on the flanks in order to protect the army from possible surprise attacks. On the battle field they were used mostly as support troops, and in the case of a chasing they were the most appropriate because of their mobility.

The introduction of the mounted archers diversifies the harassment possibilities especially if the adversary has a solid and ordinate infantry ${ }^{49}$. If the army would attack, they were the ones to usually open hostilities, their purpose being to create confusion, to demoralize and disorganize the enemy by causing great losses form afar, in order to ensure the success of the main charge. The mounted archers are often used in pursuits, because of their mobility, the terror and disorder they bring to the enemy's retreating lines. Also, because their weapons allow fighting form afar, their integrity is not endangered ${ }^{50}$. They were extremely efficient especially in chasing and dispersing the demoralized heavy cavalry who missed its charge and is running, because they were not forced to fight in block and were a lot lighter and

\footnotetext{
$40 \quad$ FLAVIUS JOSEPHUS, $B J$ 2.500-2.501; 3.66-3.69; 5.47-5.49.

41 TACITUS, Ann. 2.17.

42 AMMIANUS MARCELLINUS 16.12.7.

43 VEGETIUS, passim.

44 MCALLISTER 1993, 5.

45 MAURICIUS, 12; SCHEUERBRANDT 2004, 50.

46 RUSCU 1996, 216.

47 DIXON/SOUTHERN 1992, 119.

48 CHEESMAN 1914, 82-84.

49 T,ENTEA 2012, 102.

50 MCALLISTER 1993, 9
}

faster ${ }^{51}$. If the enemy doesn't have mounted archers in order to counter the attacks, it could suffer important losses ${ }^{52}$. The archers were extremely useful combined with the heavy cavalry because they were able to create breaches in the enemy's defense line, breaches that were exploited to the maximum by the heavy cavalry ${ }^{53}$.

The usual tactic that they adopted was the following: the archer rode towards the enemy shooting straight ahead. When he reached the effective range of action he turned to the right and rode parallel with the enemy, firing as many arrows as possible in the enemy's direction. The archer was ready to turn right if the enemy tried to approach ${ }^{54}$. Afterwards he would turn with its back and probably would shoot a few arrows during the retreat. Since in this case it was quite difficult to take aim, the purpose was to send a rain of arrows toward the zone occupied by the enemy in order for some of them to find their target. In these cases speed is more important than precision ${ }^{55}$. It is approximated that during an attack o this kind, an archer would manage to shoot approximately 3 arrows in 1.5 seconds $^{56}$. One archer can empty a quiver of 30 arrows in 3 minutes ${ }^{57}$, and in order to enhance the number of shot arrows the Sasanians invented a device called panjagan, which allowed the archer to send five arrows at a time ${ }^{58}$.

Another tactic often encountered in the East archers on horse was the flight simulation while continuing to shoot arrows over the back of the horse. This technique named "partic" or "retreat" was probably used by archers to escape without wounds in case they would finish their arrows or to lure the enemy into a trap ${ }^{59}$.

It is possible that the archers had also spears in order to reduce their vulnerability if they were in danger of being caught by the enemy. In order to escape their followers, from an attempt of circling them or a heavy cavalry charge, they had the advantage of mobility ${ }^{60}$ given by their equipment's lightness and the horses' amazing speed and total submission ${ }^{61}$. If the arrows were depleted, the archers on horse can renew their stock quickly and easily thanks to their great speed ${ }^{62}$.

The mounted archers are faster that the pedestrian ones, but they can use this advantage only in the open field. They can get closer or further from the enemy at greater speed and envelop the enemy line ${ }^{63}$. Also, if the need arises they can dismount and fight just like the pedestrian archers do. If they have to cross a river, they can do it much faster that the pedestrian ones, facilitating even the crossing for the latter ones ${ }^{64}$.

The archers on horse use smaller bows than the RUSCU 1996, 216.

DIXON/SOUTHERN 1992, 143.

PLUTARCH, CRASSUS 24-25; CASSIUS DIO 40.22-40.24; EADIE 1967, 164; LUTTWAK 1976, 43; COWAN 2011A, 35.

4 GOLDSWORTHY 1996, 67

GOLDSWORTHY 1996,188, 233.

LATHAM, PATERSON 1970, 142; GOLDSWORTHY 1996, 232.

HEATH 1980 apud MILLER/MCEWEN/BERGMAN 1986, 188.

FARROKH/MCBRIDE 2005, 14.

PLUTARCH, Crassus 24.5-24.6; PEDDIE 1996, 91; MONTAGU 2006, 67.

THORNE 2007, 223.

COULSTON 1985, 293-4; DIXON/SOUTHERN 1992, 77.

PLUTARCH, Crassus 25.

MCALLISTER 1993, 38

4 CAESAR, BG 7.56. 
pedestrian ones $\mathrm{do}^{65}$, because they are easier to handle when the archer has to change the direction of shooting over the horse's neck. If they were to use bigger arrows and bows, the quiver might descent to much and impend the horse in its movement ${ }^{66}$. Also with a bow like this they can shoot straight ahead, over the horse's head, without the horse and its archer being hindered ${ }^{67}$.

The horses used by the archers needed special training in order not to respond negatively when the archer squeezed the knees and raised while shooting ${ }^{68}$.

A moving horse represents a very instable "shooting platform ", such as the accuracy of hitting a target while running was quite reduced. That is why its purpose in that moment was not to hit a certain target, but to send as many arrows towards the enemy as possible, in order for a part of them to find a target. As we can see in these cases precision comes second to firing speed ${ }^{69}$. Still, this irregular movement was favorable to the archers because they became themselves elusive targets ${ }^{70}$.

A single archer was enough, no matter if he was on horse or on foot, in order to create disorder and to terrorize the enemy; he has a certain immunity given by the range of action, and when feeling threatened he can retreat to shelter ${ }^{71}$. An archer can deliver deadly blows from great distances to individual targets or by shooting in the enemy as a whole. He can shoot several arrows per minute until his quiver is empty, when he has to return for a refill of the arrows or tries to reuse the ones fallen in his area ${ }^{72}$.

The archers were the most efficient harassment troops used by the Roman army, proof being the large number of this type of troops in the Empire. Their usage alongside slingers, creates panic amongst the adversaries because usually they see to late the projectile that hits them and are unable to defend themselves. Unfortunately the archers are very vulnerable to attacks because of their lack of armor ${ }^{73}$ in order to move efficiently, and the fact that using a shield while shooting a bow is impossible ${ }^{74}$. That is why in order to be truly efficient, they have to be accompanied by spearmen and heavy infantry troops to provide protection ${ }^{75}$, or to be positioned in difficult accessible places ${ }^{76}$.

Another weakness of these troops is the fact that archers are impossible to use in rain or snow, because the bow's cord, made out of skin or tendons, looses its elasticity on account of humidity ${ }^{77}$.

\footnotetext{
65 SPEIDEL 1994, 105; COULSTON 1985, 245-246; DIXON/SOUTHERN $1992,53$.

66 COULSTON 1985, 246; MCALLISTER 1993, 27, 41.

67 BRADBURY 1985, 12.

68 DIXON/SOUTHERN 1992, 119.

69 GOLDSWORTHY 1996, 67.

70 GOLDSWORTHY 1996, 232.

71 MCALLISTER 1993, 38.

72 MCALLISTER 1993, 38

73 VEGETIUS 1.20; 2.15 notes that between those for who the armor was not specific, it has been imposed because they could not wear shields.

74 MCALLISTER 1993, 37-38.

75 TACITUS, Ann. 2.17; GOLDSWORTHY 1996, 190.

76 ARRIAN, Alani 12-21; TACITUS, Ann. 1,16.

77 FRONTINUS 4.8.30. For details on bow and arrow see URECHE 2013.
}

\section{REFERENCES:}

\section{BRADBURY 1985}

Bradbury, J., The Medieval Archer (Woodbridge: The Boydell Press).

\section{CHEESMAN 1914}

Cheesman, G. L., The Auxilia of the Roman Empire (Oxford: Clarendon).

COULSTON 1985

Coulston, J., Roman Archery Equipment. In: Bishop M. C. (ed.), The Production and Distribution of Roman Military Equipment [BAR I.S. 275], (Oxford: Archaeopress), 220-336.

COWAN 2011a

Cowan, R., Cataphracts and siegecraft; Adapting to the enemy in the Sassanid wars, Ancient Warfare 3, 33-37.

COWAN 2011b

Cowan, R., Later Roman Battle Tactics. In: Koepfer/C., Himmler/F. W., Löffl, J. (eds.), Die römische Armee im Experiment (Berlin: Frank \& Timme), 267-285.

\section{DAVIES 1977}

Davies, J. L., Roman Arrowheads from Dinorben and the ,Sagittarii' of the Roman Army, Britannia 8, 257-270.

DIXON/SOUTHERN 1992

Dixon, K., Southern, P., The Roman Cavalry (London: Batsford).

EADIE 1967

Eadie, L. W., The Development of Roman Mailed Cavalry, Journal of Roman Studies 57, 1/2, 161 - 173.

FARROKH/MCBRIDE 2005

Farrokh, K., McBride, A., Sassanian Elite Cavalry AD 224642 (Oxford: Osprey).

\section{FEUGÈRE 1993}

Feugère, M., Les armes de Romains de la République à l'Antiquité tardive (Paris: Errance).

\section{GILLIVER 2005}

Gilliver, K., Caesar's Gallic War (New York/London: Routledge).

GILLIVER 2008

Gilliver, C.M., Battle, In: Sabin, P./van Wees, H./Whitby M. (eds.), The Cambridge History of Greek and Roman Warfare. II.I: The Late Republic and the Principate (Cambridge: University Press), 122-157.

GOLDSWORTHY 1996

Goldsworthy, A. K., The Roman Army at War 100 BC - AD 200 (Oxford: Clarendon).

HEATH 1980

Heath, E. G., Archery: a military history (London: Osprey).

\section{LATHAM/PATERSON 1970}

Latham, J. D., Paterson, W. F., An English version and exposition of a Mameluke work on archery (ca. A.D. 1368), (London: Holland P.).

\section{LUTTWAK 1976}

Luttwak, E., The Grand Strategy of the Roman Empire (Baltimore-London: The Johns Hopkins University Press)

\section{MCALLISTER 1993}

McAllister, D. W., Formidabile Genus Armorum: The Horse Archers of the Roman Imperial Army (British Columbia: Master Thesis).

\section{MILLER/MCEWEN/BERGMAN 1986}

Miller, R., McEwen, E., Bergman, C., Experimental Approaches to Ancient near East Archery, World Archaeology, 18, 2, Weaponry and Warfare, 178-195.

\section{MONTAGU 2006}

Montagu, J. D., Greek and Roman Warfare: Battle, Tactics and Trickery (London: Greenhill Books). 


\section{MORSE 1885}

Morse, E. S., Ancient and Modern methods of arrowrelease, Bulletin of the Essex Institute 17.

PEDDIE 1996

Peddie, J., The Roman War Machine, (Boduin: Sutton Pub.).

RUSCU 1996

Ruscu, D., Ruscu, L., „EKTA $\Xi I \Sigma$ KATA A $\Lambda$ AN $\Omega N ”$ a lui Arrian şi strategia defensivă a Imperiului Roman epocă hadrianică, Ephemeris Napocensis 6, 205-235.

SCHEUERBRANDT 2004

Scheuerbrandt, J., Exercitus. Aufgaben, Organisation und Befehlsstruktur romischer Armeen wahrend der Kaiserzeit (Freiburg: Dissertation Albert-Ludwigs-Universität Freiburg) SPEIDEL 1994

Speidel, M. P., Legionary Horsemen on Campaigns, Saalburg Jahrbuch 47, 36-39.

STEPHENSON 1999

Stephenson, I. P., Roman Infantry Equipment. The Later Empire, (Stroud: Tempus).

\section{THORNE 2007}

Thorne, Battle, Tactics and the Emergence of the Limites in the West. In: Erdkamp, P. (ed.) - A Companion to the Roman Army (Mladen/Oxford/Victoria: Blackwell) 218-234.

\section{TTENTEA 2007}

Tentea, O., Auxilia Commagenorum in Dacia, Acta Musei Napocensis 41-42/1, 2004-2005 (2007), 141-160.

\section{ȚENTEA 2012}

T,entea, O., Strategies and tactics or just debates? An overview of the fighting style and military equipment of Syrian archers, Studia Universitatis Babeş-Bolyai, Historia, 57/1, 101-115.

URECHE 2013

Ureche, P., The Bow and Arrow during the Roman Era, Ziridava 27, 183-196.

\section{WHEELER 2007}

Wheeler, E. L., The Army and the Limes in the East. In: Erdkamp, P. (ed.) - A Companion to the Roman Army (Mladen/Oxford/Victoria: Blackwell), 235-266. 


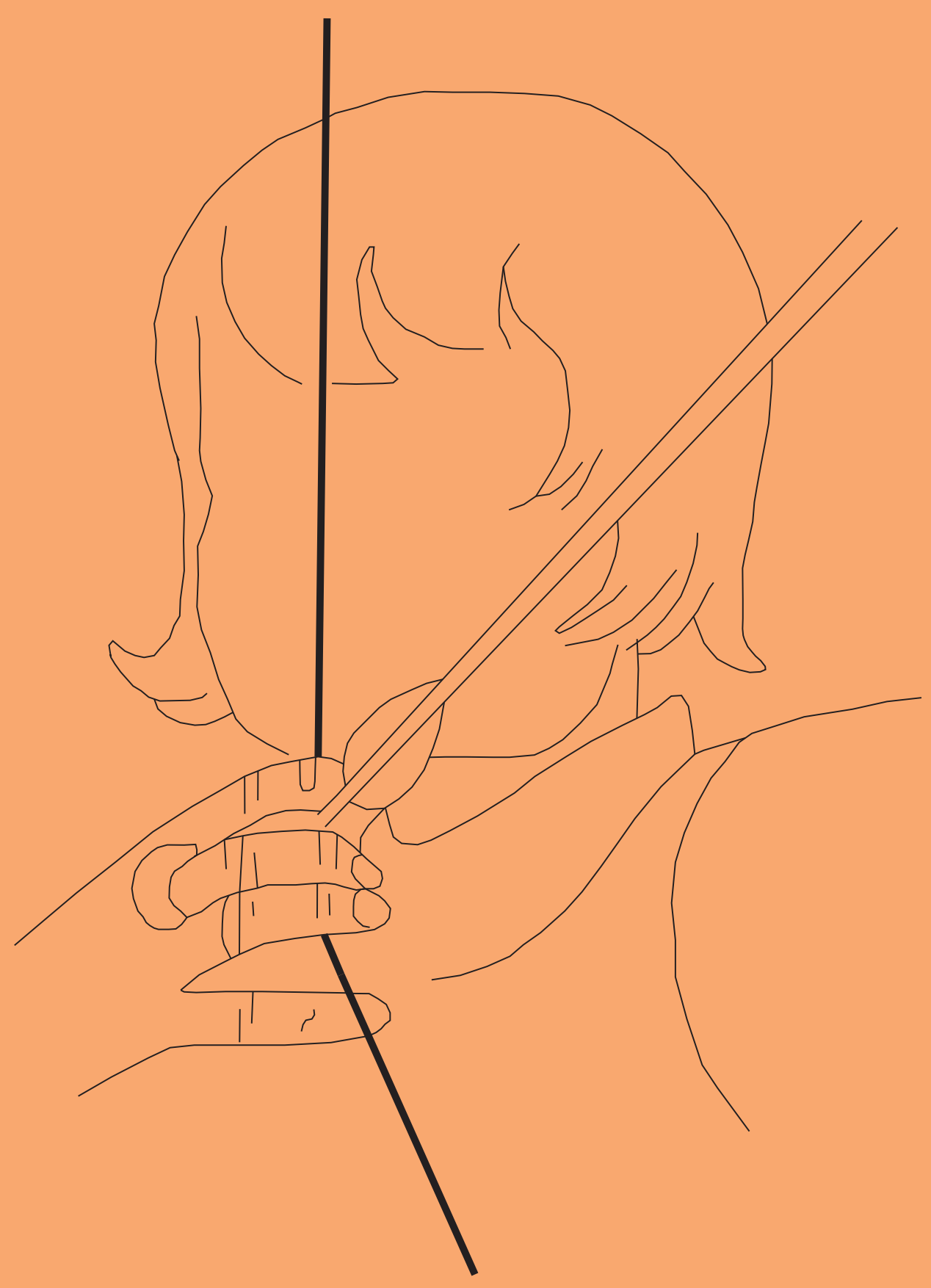

Fig. 1: Mediteranean Draw (redrown after Baier, Bowers, Fowkes, Schoch 1976, 37). 


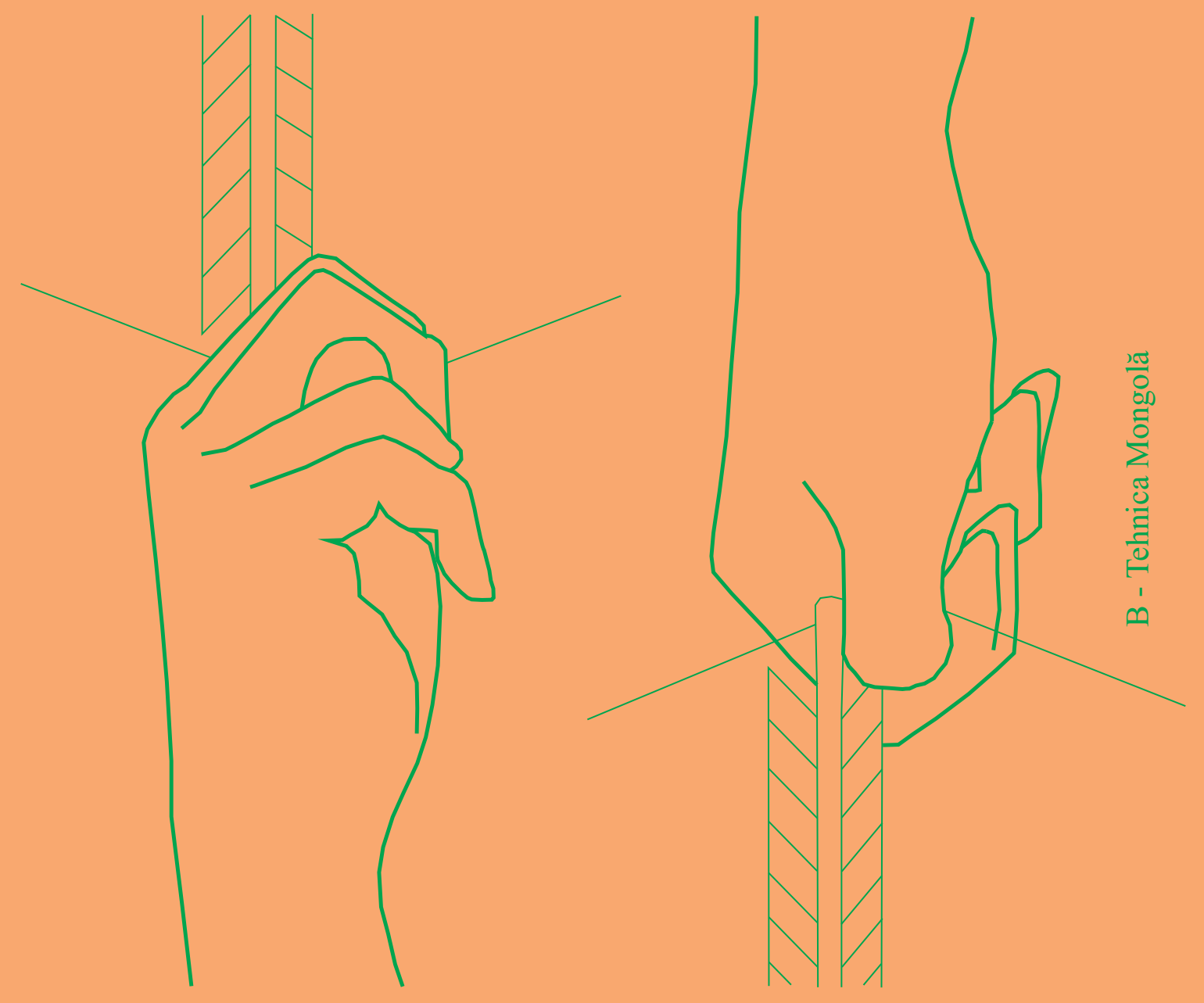

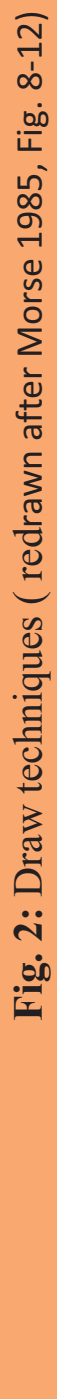




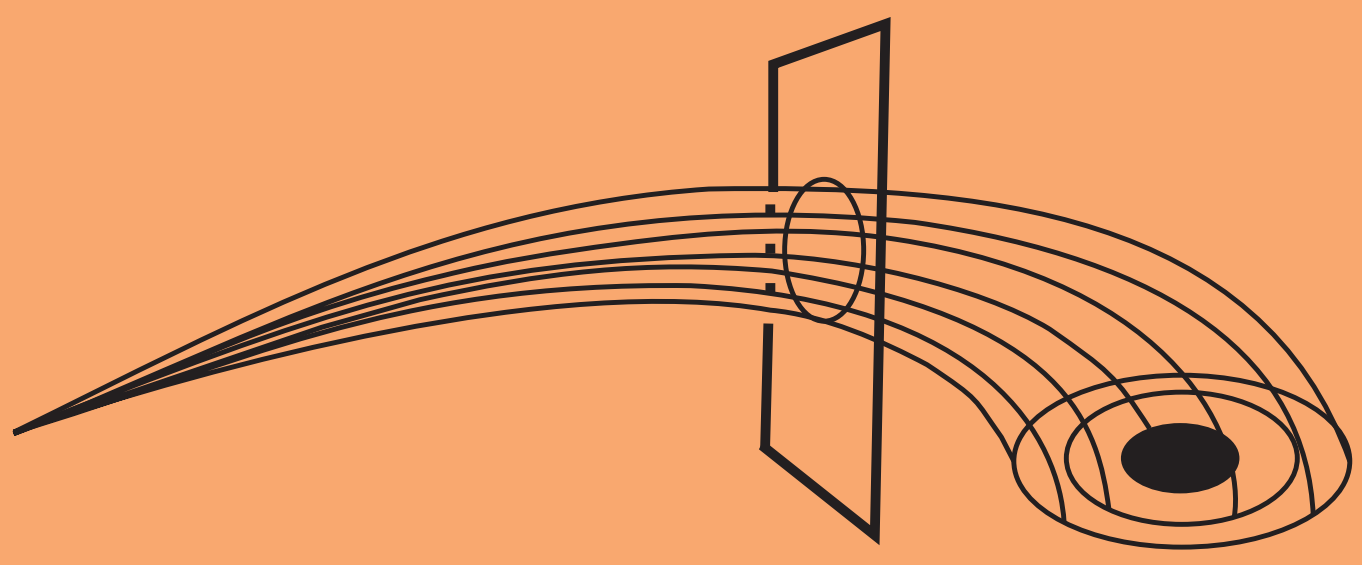

A
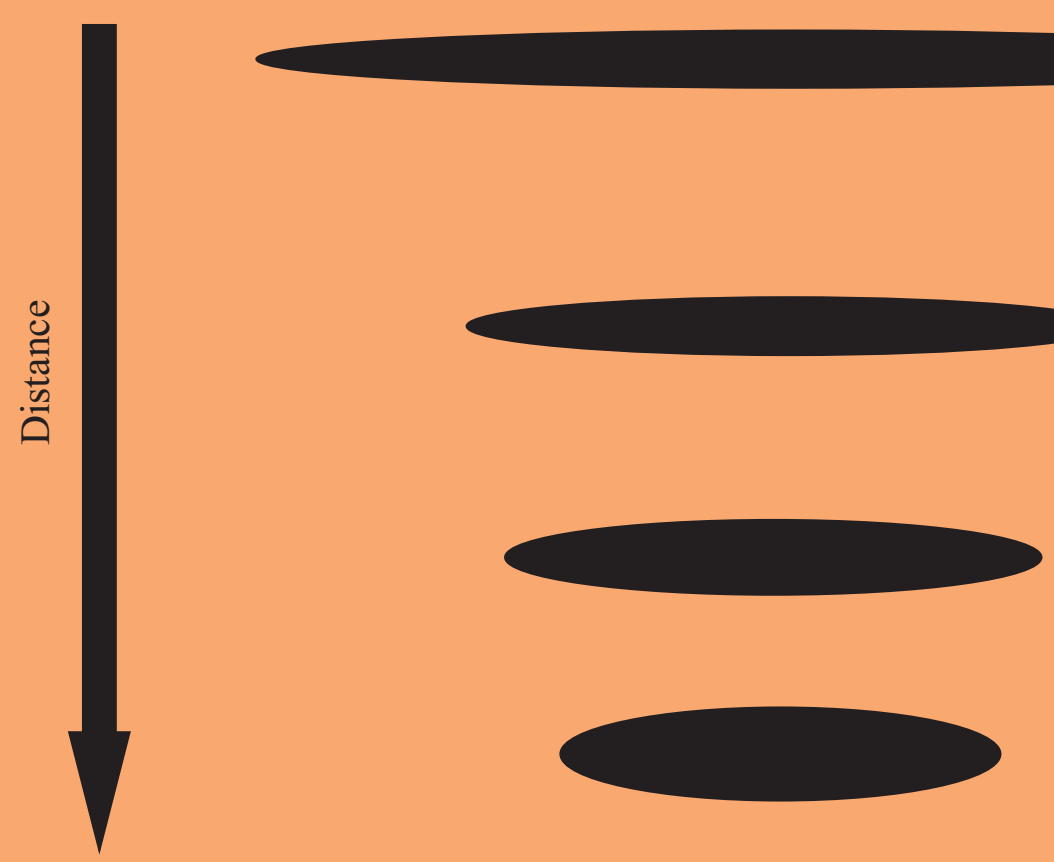

B

Fig. 3: A - Cone of Fire (redrawn after McAllister 1993, 122, Fig. 25)

B - Beaten zone (redrawn after McAllister 1993, 123, Fig. 26) 